\title{
Fine structure of protonema in Funaria hygrometrica
}

\author{
F. MLODZIANOWSKI
}

Few data are available concerning the submicroscopic morphology of mosses. Valanne (1966) described the ultrastructure of germinating spores in Ceratodon purpureus, Zurzycki (1968) the submicroscopic organisation of the ,leaf" cells in Funaria hygrometrica and Sun (1962) the structure and development of chloroplasts in the same species. No studies have been made till now on the ultrastructure of the protonema which represents in the development of mosses a stage with a rather primitive, filamentous morphology. It is also a conveniant material for various cytological and physiological studies, and therefore the investigation of its fine structure seemed to be of interest and use for possible future experiments.

\section{MATERIAL AND METHODS}

The protonema of Funaria hygrometrica Hedw. was grown from spores in a nutrient solution containing in addition to mineral salts glucose at $0.25 \%$ (Szweykowska and Handszu 1965). The cultures were kept in continuous light of about 1000 lux. After 10 days the protonema was transferred for another 6 days to medium without glucose, to make the growth conditions similar to those used in our experiments with growth stimulators and inhibitors (Młodzianowski, Szweykowska and Schneider 1970). The protonema was then fixed for $2 \mathrm{hrs}$. and at $4^{\circ} \mathrm{C}$ in a $1 \%$ $\mathrm{OsO}_{4}$ solution in a phosphate buffer of $\mathrm{pH} 7.0$ or in $\mathrm{KMnO}_{4}$ according to Luft (1956).

The material was dehydrated with ethanol and propylene oxide, and embedded in Epon 812. The sections were stained with uranyl acetate and lead citrate according to Reynolds (1963). The sections were examined and the micrographs taken with the JEM-7a electron microscope (some micrographs - Figs. 3, 10 and 11 with the EM-5 electron microscope).

\section{RESULTS AND DISCUSSION}

The protonema of mosses consists of branched filaments composed of a single row of cells. The cells of Funaria hygrometrica contained numerous chloroplasts evenly distributed on the whole cell length (Fig. 1). A distribution of various organel- 
les in a transverse cell section is shown on the micrograph in Fig. 5. The details of the ultrastructure of the individual cell components are presented on Figs. $2-15$.

In the electron microscope, the cell walls were dark after osmium fixation indicating their strong reducing capacity of $\mathrm{OsO}_{4}$. Similar observations were made by Zurzycki (1968). The longitudinal walls had a micro-fibrillar structure with no layer differentiation. The transverse walls were considerably thinner than the longitudinal ones and after osmium fixation showed a distinctly lighter layer in the region of middle lamella (Figs. 2 and 7). Numerous plasmodesms penetrating the transverse walls could be seen after $\mathrm{KMnO}_{4}$ (Fig. 3), as well as $\mathrm{OsO}_{4}$ fixation (Fig. 7) which indicates close connections between the protoplasts in the long protonema filament.

The plasmalemma showed often a wavy outline on the micrographs and was not closely contiguous to the cell wall (Figs. 2 and 13). A large central vacuole was limited by a tonoplast (Figs. 4 and 5).

The granular structure of cytoplasm was visible only after osmium fixation. The granules of the size of $60-120 \AA$, apparently ribosomes, were variously distributed. They often concentrated near the cell walls and occasionally formed polysome configurations (Fig. 13).

Endoplasmic reticulum was sparingly represented in form of single tubules which occurred along the cell walls and occasionally formed some distensions (Fig. 2).

The Golgi apparatus was composed of $1-5$ cisterns (Figs. 12 and 13). Vesicles with higher electron density than the ground cytoplasm were observed at the distended ends and around the cisterns. They were observed mainly near the cell walls which may indicate their participation in cell wall formation.

Many bodies of more or less spherical shape and 0.6-1 $\mu \mathrm{m}$ size were present in the cytoplasm. With permanganate fixation, they consisted of an irregularly shrunken single membrane surrounding an electron transparent content (Fig. 3). With osmium fixation, they showed and electron dense periphery zone in which the boundary membrane was hardly distinguishable (Fig. 14).

Occasionally electron dense strands penetrated from the periphery zone towards the center (Fig. 4). The core was electron transparent or occasionally showed some fine fibrillar structures (Figs. 7 and 8). The bodies resembled those described by Sorokin and Sorokin (1967) in Campanula as spherosomes. On the other hand, they also showed a distinct similarity to oil globules in the liverwort Bazania trilobata (Pihakaski 1968). In a material not presented in this paper where glutaralde: hyde fixation was used, these bodies closely resambled structures commonly described as typical lipid bodies (Fawcett 1966; Pihakaski 1966). Therefore, the term lipid bodies has been accepted by the author to designate these cell structures.

A rather different type of structures was represented by much less numerous, oval, kidney or pear-shaped bodies of about $1 \mu \mathrm{m}$ size consisting of a single membrane surrounding a homogenous, densely granulated content (Figs. 4, 5, 14). Some of them exhibited dense inclusions (Fig. 15). Their structure resembled ,microbodies" pescribed by Frederick et al. (1968). However, they were not as numerous in pro- 
tonema cells as they were according to Frederick et al. in cells of various tissues in higher plants. On the average, $1-2$ microbodies were found in one longitudinal section of a protonema cell, whereas the lipid bodies were present in a number of 10-20. Therefore, it is hardly to expect that the microbodies in Funaria posses functions similar to those ascribed to them by Frederick et al. (1968), i.e. functions of lizosomes and animal microbodies. The terminology and opinions about the morphology and function of structures described here as lipid bodies and microbodies are wery different (Frey-Wissling and Mühlethaler 1965; Wałek-Czernecka 1965; Olszewska 1967; Sorokin and Sorokin 1957; Frederick et. al. 1968; Matile 1968; Matile and Spichiger 1968), and it is thus difficult to classify them correctly without additional cytochemical and biochemical investigations.

The cell nucleus had an irregular shape. The nucleoplasm had a homogeneous finely granular structure. The structure of the nucleolus was more electron dense. The nucleus was surrounded by two unit membranes separated by light space. The outer membrane formed evaginations which indicated a possibility of separating vesicles surrounded by a unit membrane (Fig. 6).

The oval and rod-like profiles of mitochondria were most frequently found in the neighbourhood of chloroplasts, with the envelopes of both organelles coming into a close contact. They possessed tubular structure and contained a homogenous finely granulated matrix (Figs. 5, 7).

The chloroplasts were surrounded by a double membrane. Between the surrounding unit membranes, vesicles bounded by a single membrane (Fig. 10) could be observed which resembled the ,Körperchen in der Plastidenmembran" described by Diers (1966). Grana could be distinguished in the lamellar system which had

\section{PLATE I}

Fig. 1. Protonema cells of Funaria hygrometrica in the light microscope Komórki protonemy Funaria hygrometrica w mikroskopie świetlnym

Fig. 2. Fragment of a longitudinal section of a protonema cell, $\mathrm{KMnO}_{4}$. Longitudinal and trans versal cell wall (CW), ER - endoplasmic reticulum, $\mathrm{Pl}$ - plasmalemma. $30000 \times$

Fragment pođłużnego przekroju przez komórkę protonemy, $\mathrm{KMnO}_{4}$. Ściana pođłużna i węższa od niej ściana poprzeczna (CW), ER — retikulum endoplazmatyczne, $P l$ - plazmalemma. $30000 \times$ Fig. 3. Longitudinal section of a protonema cell, $\mathrm{KMnO}_{4}$. Ch-chloroplast, $\mathrm{CW}$-cell wall, Pld - plasmodesmata, $L$ - lipid body. $24000 \times$

Przekrój podłużny przez komórkę protonemy, $\mathrm{KMnO}_{4}$. $\mathrm{Ch}$ - chloroplast, $\mathrm{CW}$ - ściana komórkowa, Pld - Plazmodesma, $L-$ ciało thuszczowe. $24000 \times$

\section{PLATE II}

Fig. 4. Longitudinal section of a protonema cell, $\mathrm{OsO}_{4} . \mathrm{Ch}-$ chloroplast, $\mathrm{CW}-$ cell wall, $M$ - mitochondrion, $M i$ - microbody, $L$ - lipid body, $T$ - tonoplast, $V$ - vacuole. $20000 \times$ Przekrój pođłużny przez komórkę protonemy, $\mathrm{OsO}_{4}$. $\mathrm{Ch}$ - chloroplast, $\mathrm{CW}$-ściana komórkowa, $M$ - mitochondrium, $M i$-mikrociało., $L$ - ciało tłuszczowe, $T$-tonoplast, $V$ - wakuola. 


\section{PLATE III}

Fig. 5. Transverse section of a protonema cell. $\mathrm{Ch}$ - chloroplast, $M-$ mitochondrion, $\mathrm{Mi}-$ microbody, $N$ - nucleus, $L$ - lipid body, $T$ - tonoplast, $V$ - vacuole. $7000 \times$

Przekrój poprzeczny przez komórkę protonemy. $C h-$ chloroplast, $M-$ mitochonđrium, $M i-$ mikrociało, $N$ - jądro, $L-$ ciało tłuszczowe, $T$ - tonoplast, $V$ - vakuola. $7000 \times$

\section{PLATE IV}

Fig. 6. Nucleus $(N)$. The outer membrane of nucleus envelope formes evagination, $\mathrm{OsO}_{4} \cdot \mathrm{Nu}-$ nucleolus. $15000 \times$

Jądro $(N)$. Widoczny pęcherzyk utworzony z zewnętrznej błony jądrowej, OsO $\mathrm{O}_{4} \cdot \mathrm{Nu}$ - jąderko. $15000 \times$

Fig. 7. Transversal wall $(\mathrm{CW})$ with a distinct layer of middle lamella and numerous plasmodesmata

$(\mathrm{Pld}), \mathrm{OsO}_{4} . \mathrm{Ch}$ - chloroplast, $\mathrm{Li}$ - lipid inclusions, $\mathrm{M}-$ mitochondrion. $30000 \times$

Ściana poprzeczna $(C W)$ z jasną dla elektronów blaszką środkową $(M l)$ i licznymi plazmodesmami $(\mathrm{Pld}), \mathrm{OsO}_{4} . \mathrm{Ch}$ - chloroplast, $\mathrm{Li}$ - inkluzje tłuszczowe, $M$-mitochondrium. 30000

\section{PLATE V}

Fig. 8. Chloroplast with laterally displaced grana discs, $\mathrm{OsO}_{4} . G-$ grana, $M t x-$ matrix, $L-$ lipid body. $30000 \times$

Chloroplast z bocznie względem siebie przemieszczonymi dyskami gran. $G$ - grana, $M t x-$ matriks, $L$ - ciała tłuszczowe. $30000 \times$

Fig. 9. Starch $(\mathrm{St})$ in the chloroplast matrix, $\mathrm{OSO}_{4} .30000 \times$.

Skrobia $(S t)$ w matriks chloroplastu, $\mathrm{OsO}_{4} .30000 \times$

Fig. 10. Two oval-shaped bodies $(B)$ between the membranes of the chloroplast envelope, $\mathrm{KMnO}_{4} .30000 \times$

Dwa owalne ciałka $(B)$ pomiędzy błonami otoczki chloropastu, $\mathrm{KMnO}_{4} .30000 \times$

Fig. 11. Distinct grana $(G)$ with associated stroma thylakoids $($ Sth $), \mathrm{KMnO}_{4} .35000 \times$

Wyraźne grana $(G)$ i tylakoidy stromy $($ Sth $), \mathrm{KMnO}_{4} .35000 \times$

\section{PLATE VI}

Fig. 12. Golgi apparatus. Numerous vesicles with electron dense contents, $\mathrm{OsO}_{4} .70000 \times$

Aparat Golgiego. Widoczne liczne pęcherzyki Golgiego z elektronowo-gęstą zawartością, OsO ${ }_{4}$. $70000 \times$

Fig. 13. Golgi apparatus near the cell wall and ribosomes $(R)$ with polysome configurations, $P l$ - plasmalemma. $50000 \times$

Aparat Golgiego w pobliżu ściany komórkowej oraz liczne rybosomy $(R)$ tworzące skupienia (polirybosomy), $\mathrm{OsO}_{4} . \mathrm{Pl}$ - plazmalemma. $50000 \times$

Fig. 14. Lipid bodies (L) and microbody (Mi), $\mathrm{OsO}_{4} .30000 \times$

Skupienia ciał tłuszczowych $(L)$ i mikrociało $(M i), \mathrm{OsO}_{4} .30000 \times$

Fig. 15. Kidney-shaped microbody with a dense inclusion, $\mathrm{OSO}_{4} .45000 \times$

Mikrociało kształtu nerkowatego $\mathrm{z}$ gęstą inkluzją, $\mathrm{OsO}_{4} .45000 \times$ 
Plate I
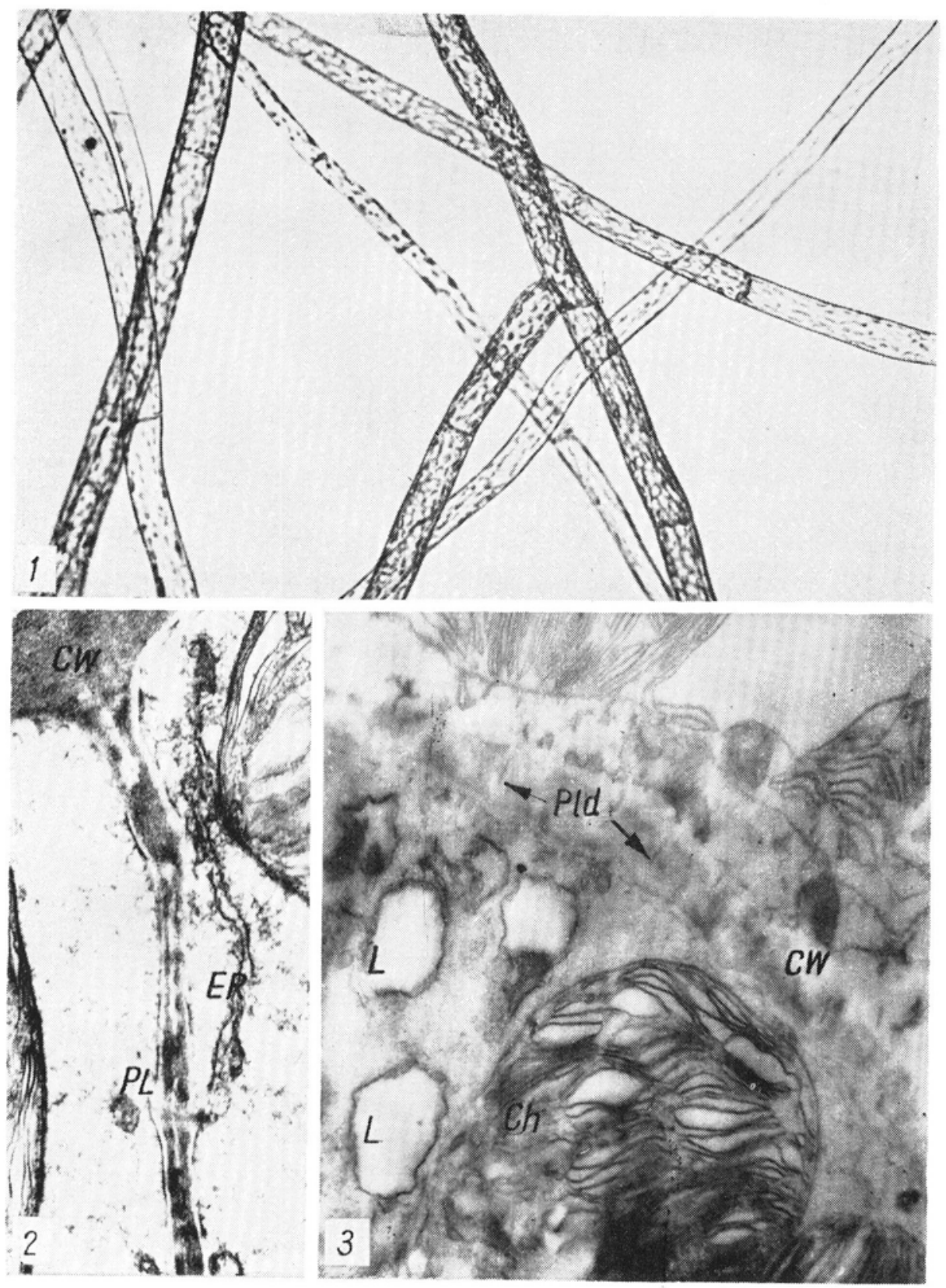
Plate II

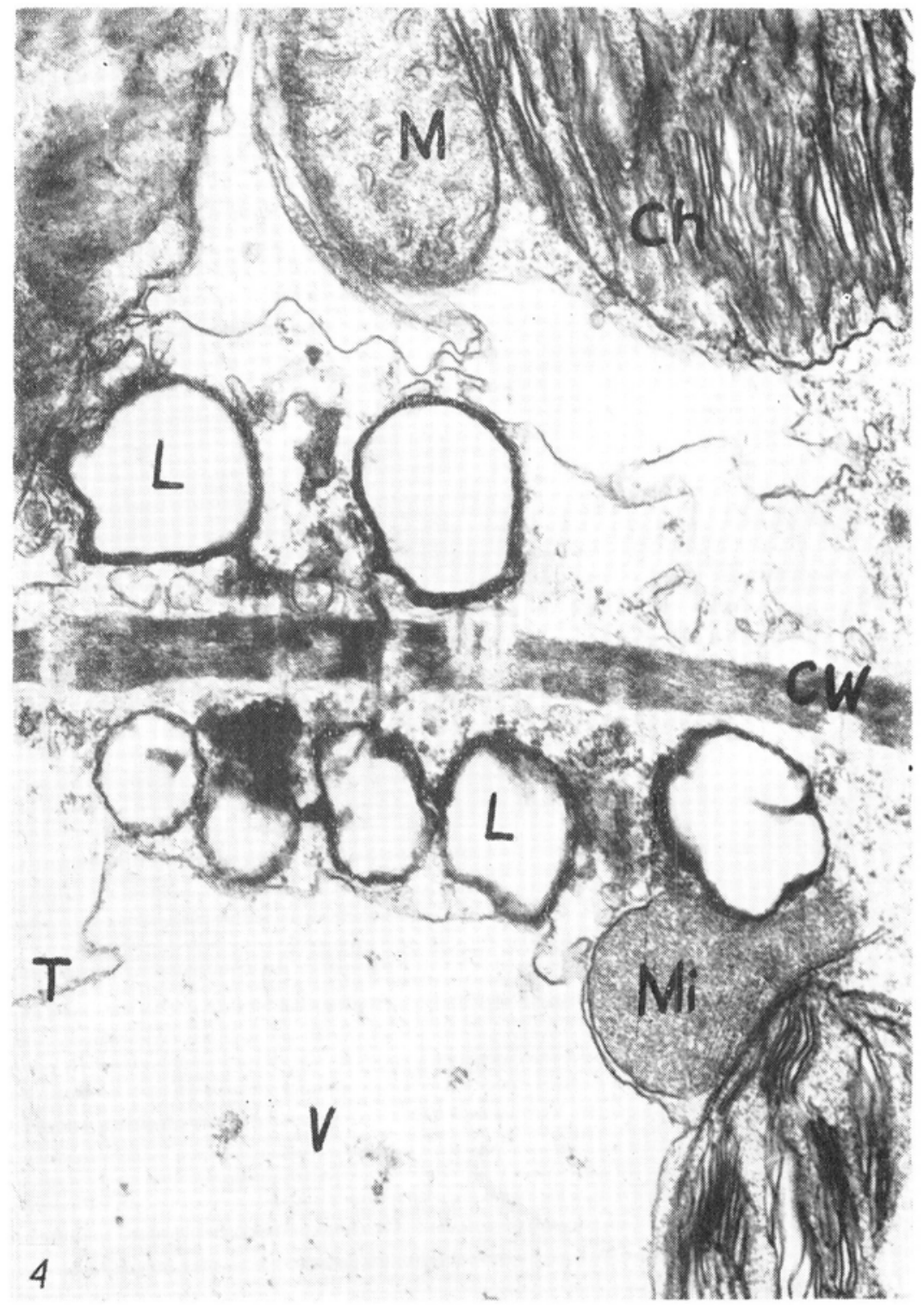


Pl ate III

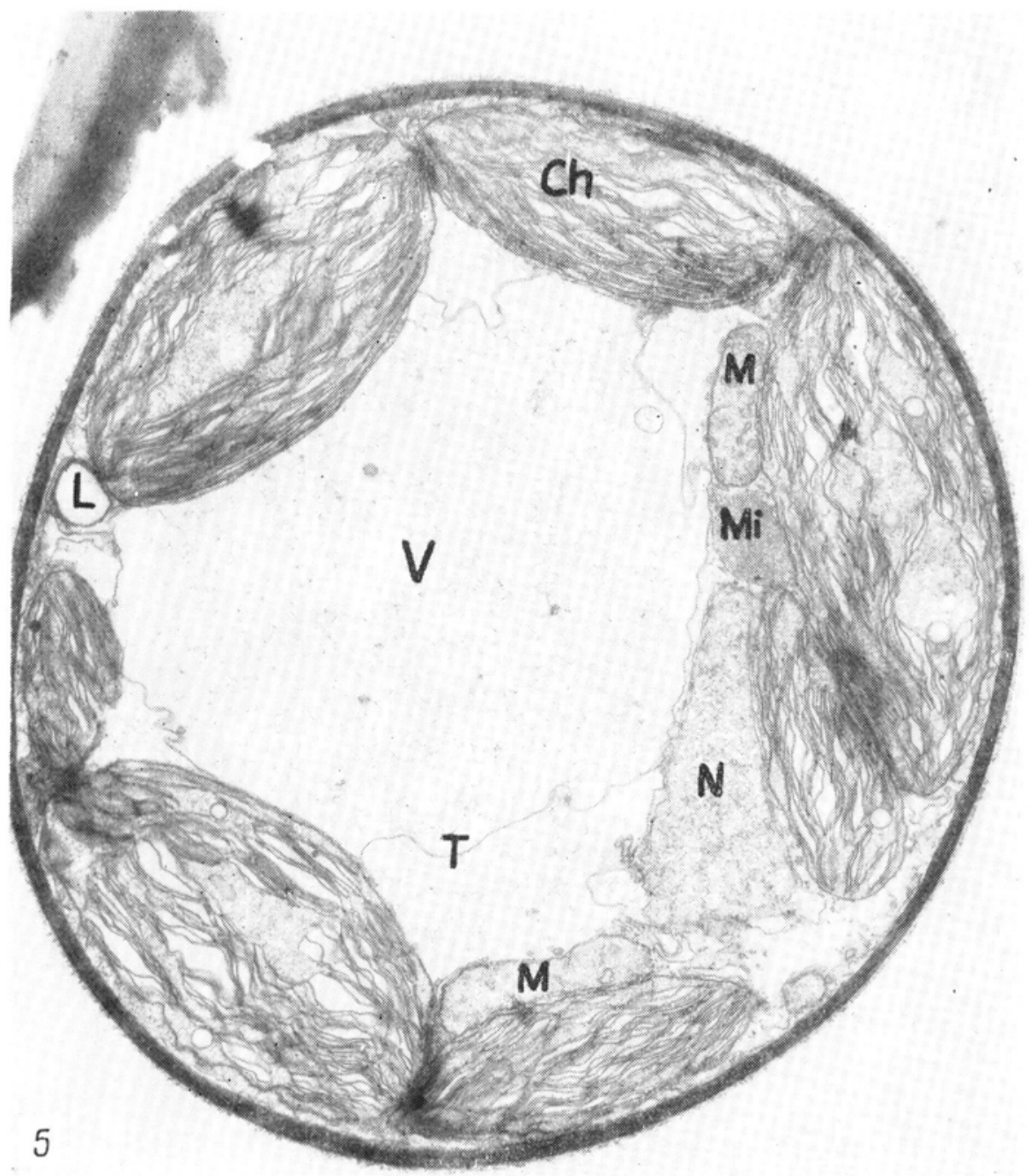


Plate IV





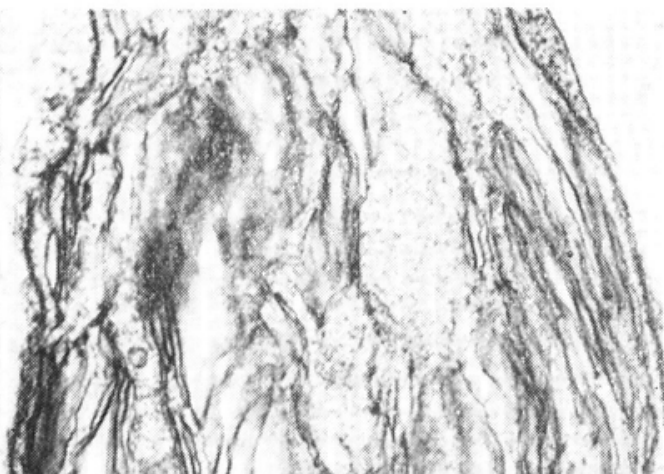

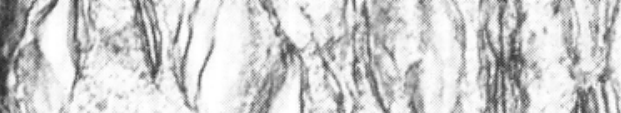



130 Mtx 3 Mtx
30120


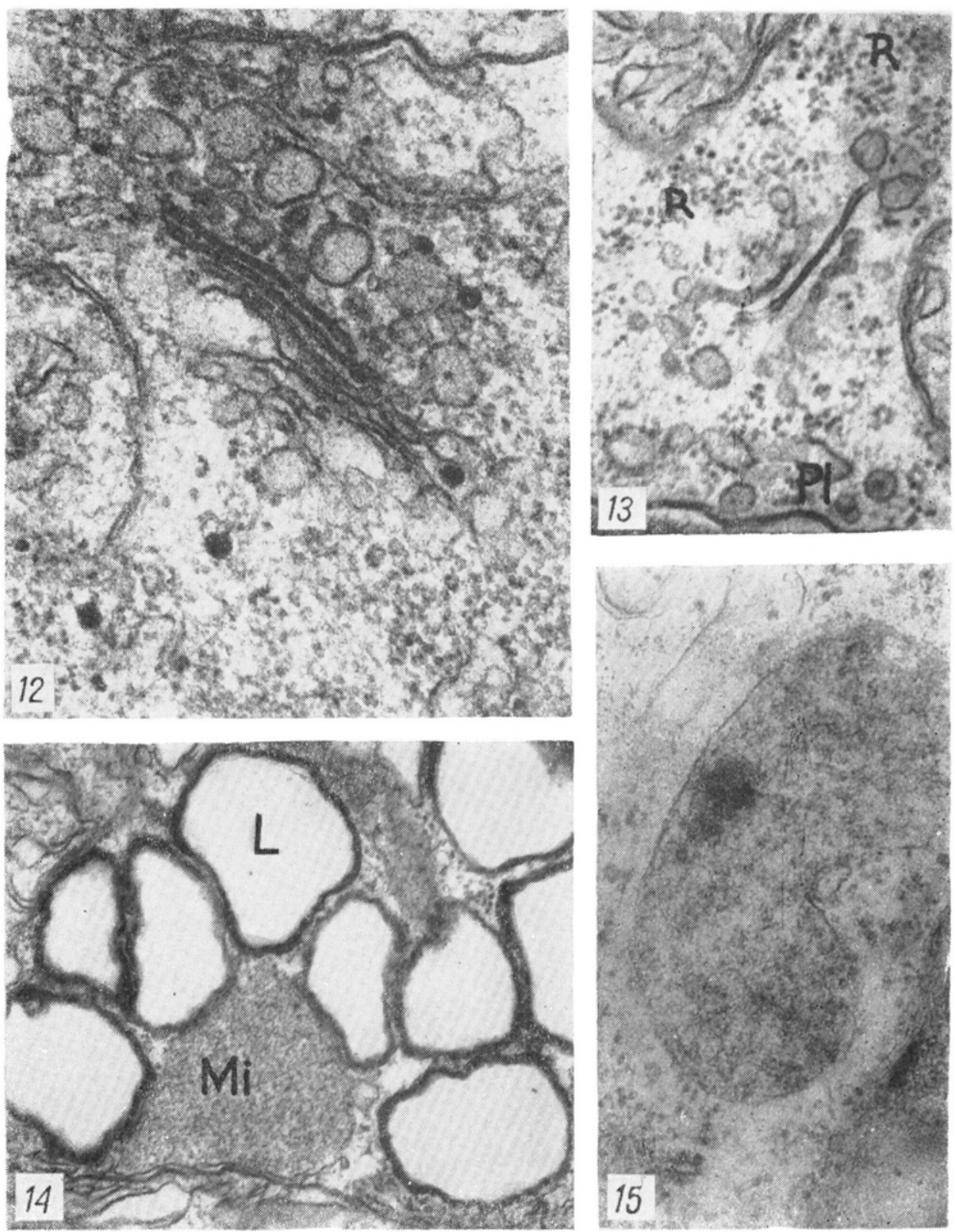
a rather loose and wavy appereance, however, they did not form as distinctly differentiated units as those found in higher plants. The grana discs were more or less laterally displaced forming a characteristic fan-shaped configuration. More distinct grana with associated stroma thylakoids are shown on Fig. 11. The matrix was uniformly finely granulated (Fig. 8). Few globules with a diameter of about $\dot{0} .1 \mu \mathrm{m}$, most probably lipoid inclusions, and starch grains were observed in the matrix (Figs. 7 and 9). The ultrastructure of the chloroplasts in the mature protonema does not differ from that described for other developmental stages of Funaria by Sun (1962) and Zurzycki (1968). Contrary to the latter author, however, peristromium was not observed in the protonema chloroplasts. The chloroplast structure of the kind occurring in Funaria has been found also in other mosses, Ceratodon (Valanne 1966) and Bryum (Sun 1962). It is more primative than that of higher plants, especially with relation to the structure of grana which in chloroplasts of higher plants have the characteristic coin-stack arrangement.

\section{SUMMARY}

The ultrastructure of the protonema in Funaria hygrometrica after fixation in $\mathrm{KMnO}_{4}$ and $\mathrm{OsO}_{4}$ has been described. The osmium fixation has proved to be better for preserving various cell structures. The structure of chloroplasts in the protonema of Funaria is more primitive when compared with higher plants. It is similar to that reported for other developmental stages of Funaria. Various cell structures as Golgi apparatus, lipid bodies and microbodies have also been described. They show similar features as corresponding organelles found in higher plants. The protonema seems to be a conveniant plant material for further cytological investigations because of its relatively simple morphology and easy culture in various experimental conditions.

The author wishes to express his thanks to dr. A Szweykowska for reading the manuscript and critical remarks, to dr. Jan Michejda (A. Mickiewicz University) for the chemicals used in this work, and to the staff of the Electron Microscope Laboratory of the A. Mickiewicz University of Poznań for technical assistance.

Department of General Botany

(Entered: June 25, 1969.)

Adam Mickiewicz University

Poznań, Stalingradzka 14, Poland

\section{LITERATURE}

Diers L., 1966, Über die dreidimensionale Gestaltung des Thylakoidsystems in den Chloroplasten, Planta 70: $322-343$.

Frederick S. E., E. H. Newcomb, E. L. Vigil and W.P. Wergin, 1968, Fine-structural characterization of plant microbodies, Planta 81: 229-252.

Luft J. H., 1956, Permanganate - a new fixative for electron microscopy, J. Biophys. Biochem. Cytol. 2: 799-802.

Matile Ph., 1968, Lysosomes of root tip cells in corn seedlings, Planta 79: 181-196.

Matile Ph., J. Spichiger, 1968, Lysosomal enzymes in spherosomes (oil droplets) of tobacco endosperm, Z. Pflanzenphysiol. 58: 277-280. 
Młodzianowski F., A. Szweykowska, J. Schneider, 1970, The effect of chloramphenicol on the ultrastructure of chloroplasts in the protonema of Funaria hygrometrica, Acta Soc. Bot. Pol. 39: 38-43.

Olszewska M., 1967, Sferosomy w świetle nowych badań, Wiadomości Botaniczne 11 : 9-31.

Pihakaski K., 1966, An electron microscope study on the oil bodies of two hepatic species, Protoplasma 72: 393-399.

Pihakaski K., 1968, A study of the ultrastructure of the shoot apex and leaf cells in two liverworts, with special reference to the oil bodies, Protoplasma 66: 79-103.

Reynolds E. S., 1963, The use of lead citrate and high pH as an electron opaque stain in electron microscopy, J. Cell. Biol. 17: 208-212.

Sorokin H. P. and S. Sorokin, 1966, The spherosomes of Campanula persicifolia L., Protoplasma 62: 216-236.

Sun C. N., 1962, Submicroscopic structure and development of the chloroplasts of Funaria hygrometrica and Bryum sp., Cytologia (Tokyo), 27: 333-342.

Szweykowska A. and A. Handszu, 1965, The effect of kinetin on gametophyte development and protein synthesis in the moss Ceratodon purpureus, Acta Soc. Bot. Pol. 34: 79-81.

Valanne N., 1966, The germination phases of moss spores and their control by light, Ann. Bot. Fenn. 3: 1-60.

Zurzycki J., 1968, Properties and localization of the photoreceptor active in displacements of chloroplasts in Funaria hygrometrica. IV. Electron microscopy, Acta Soc. Bot. Pol. 37: 3 -9.

\section{Ultrastruktura splątka Funaria hygrometrica}

\section{Streszczenie}

W pracy opisana została ultrastruktura splątka Funaria hygrometrica po utrwaleniu w $\mathrm{KMnO}_{4}$ i $\mathrm{OsO}_{4}$. Utrwalenie osmem okazało się lepsze dla zachowania różnych struktur komórkowych.

Stwierdzono bardziej prymitywną budowę chloroplastów protonemy Funaria hygrometrica w porównaniu $\mathrm{z}$ chloroplastami roślin wyższych i potwierdzono dane na ten temat znane z literatury dla innych stadiów rozwojowych tego samego gatunku. Opisano szereg struktur komórkowych w tym aparat Golgiego, mikrociała i ciała lipidowe, wykazujących buđowę zasadniczo pođobną do analogicznych organelli roślin wyższych.

Materiał ze względu na łatwość hođowli i prostą budowę morfologiczną wyđaje się być dogodny dla dalszych bađań cytologicznych z uwzględnieniem różnych warunków eksperymentu. 